\title{
Sjálfbært mataræði til bjargar
}

Nýverið birtist í Lancet grein eftir alpjóðlegan vísindahóp sem kallast EAT ${ }^{1}$. Hópurinn samanstendur af 37 vísindamönnum sem hafa á síðustu premur árum unnið að pví að setja fram vísindaleg gögn og útreikninga sem sýna hvernig pjóðir heims geta tekist á við aðkallandi vandamál tengd fæðuframboði og mataræði. Hópurinn hefur sett fram viðmið um mataræði sem styður að:

- til sé nægur matur fyrir jarðarbúa árið 2050

- matvælaframleiðsla skilji eftir sig minna kolefnisfótspor

- færri glími við lífstílssjúkdóma sem tengjast mataræði

- fækkun ótímabærra dauðsfalla

Í greininni er farið yfir núverandi stöðu í aðalatriðum varðandi pessi mál. Meðal pess sem kemur fram er að $30 \%$ af losun gróðurhúsalofttegunda og $70 \%$ af notkun fersks vatns kemur til vegna matvælaframleiðslu. Ræktun kjöts krefst mestrar nýtingar auðlinda (land og vatn) og losar mest af gróðurhúsalofttegundum borið saman við ræktun annarra matvæla.

Einnig kemur fram að annars vegar glíma 820 milljónir manna við vannæringu og hins vegar eru yfir tveir milljarðar manna í ofpyngd eða offitu (líkamspyngdarstuðull $\left.\geq 25 \mathrm{~kg} / \mathrm{m}^{2}\right)$. Á heimsvísu hefur tíðni offitu (líkamspyngdarstuðull $\geq 30 \mathrm{~kg} / \mathrm{m}^{2}$ ) prefaldast síðan árið 1975. Á Íslandi hefur tíðni offitu vaxið frá pví að vera 8\% árið 1990 í 27\% árið 2017. Samhliða pessari próun hefur tíðni sykursýki af gerð tvö tvöfaldast á síðustu 30 árum. Samkvæmt Global Panel on Agriculture and Food Systems for Nutrition vegur óhollt mataræði pyngra sem orsök lífstílsstengdra sjúkdóma en áfengisneysla, reykingar, vímuefnaneysla og óvarið kynlíf samanlagt².

Krabbamein er nú á dögum algengasta orsök dauðsfallaó Íslendinga yngri en 75 ára. Vitað er að hægt er að koma í veg fyrir $40 \%$ krabbameina með lífsstíl, svo sem reglulegri hreyfingu, minni tóbaksnotkun, hæfilegri líkamspyngd og hollu og fjölbreyttu mataræði. Árið 1980 voru kransæðasjúkdómar langalgengasta dánarorsök hjá yngri en 75 ára. Раð breyttist með minni reykingum, breyttu mataræði og betri meðferðum, pannig að lækkun í dánartíðni var $80 \%$ á 25 árum. Ýmsir áhættupættir útskýra meira af dánartíðni kransæðasjúkdóma en krabbameina. Lækkun á dánartíðni kransæðasjúkdóma mátti að 3/4 hlutum rekja til hagstæðra breytinga á áhættupáttum en hefði ef til vill orðið meiri ef aukning í ofpyngd og sykursýki hefði ekki vegið á móti ${ }^{3}$. Parna náðist stórkostlegur árangur í forvörnum. Раð er pví til mikils að vinna að bæta og viðhalda góðu mataræði fyrir góða heilsu.

Höfundar EAT huga að fleiru en heilsu okkar pví peir reyna að setja fram markmið um mataræði sem gæti hjálpað við að viðhalda heilsu jarðarinnar, pað er að gera neyslu okkar sjálfbæra pannig að við göngum ekki um of á gæði jarðar.

EAT-hópurinn setur fram viðmið um fæðumynstur sem kallast „flexitarian“ par sem reiknað er út magn fæðutegunda sem styðja við sjálfbærni í matvælaframleiðslu, minni losun gróðurhúsalofttegunda, betri heilsu og fækkun ótímabærra dauðsfalla. Meginhluti fæounnar ætti að koma úr jurtaríkinu en pó er líka ákveðið svigrúm fyrir dýraafurðir fyrir pá sem pað kjósa. Vísindamenn EAT-hópsins sýna fram á að hægt væri að fækka ótímabærum dauðsföllum og minnka kolefnisspor með breyttu mataræði (flexitarian) ${ }^{4}$.

Í flexitarian-mataræði eru viðmiðin fyrir helstu próteingjafana eftirfarandi miðað við vikuskammt: $100 \mathrm{~g}$ af rauðu kjöti, 200g af alifuglakjöti, $200 \mathrm{~g}$ af fiski, $350 \mathrm{~g}$ hnetur, $90 \mathrm{~g}$ egg og $525 \mathrm{~g}$ baunir/belgjurtir. Hér sést að aðaláhersla er lögð á að draga úr neyslu á dýraafurðum en ekki er langt síðan pau viðmið voru sett um allan heim (par með talið á Íslandi) að ekki væri borðað meira en 500 g vikulega af rauðu kjöti til að minnka líkur á krabbameini í ristli og endaparmi. Samkvæmt EAT-skýrslunni minnkar petta magn fimmfalt en eins og áður sagði pá er kolefnisspor tengt kjötframleiðslu pað allra hæsta borið saman við aðrar fæðutegundir.

Íslensku ráðleggingarnar um mataræði sem koma frá Embætti landlæknis (EL) miða við að neytt sé að meðaltali 3,5 1 af mjólk og/eða mjólkurafurðum á viku sem er nokkuð meira en í EAT-skýrslunni sem leggur til 1,8 1 á viku. Varðandi ráðleggingar um fitugjafa er lögð rík áhersla á ómettaða fitugjafa úr jurtaríkinu eða $280 \mathrm{ml}$ á viku. Pegar hugað er að kolvetnagjöfum ganga ráðleggingar frá EL út á að heilkornavörur séu borðaðar tvisvar á dag (til dæmis hafrar, rúgur, hýðishrísgrjón, heilhveitipasta) auk 500 gramma af ávöxtum og grænmeti daglega og er pað í samræmi við flexitarian-mataræðið. Í pessum samanburði má að lokum nefna að mælt er með minni fiskneyslu hjá EAT-hópnum (samsvarar einni máltíð á viku) en í íslensku ráđleggingunum. Í pví tilviki mætti mögulega rökstyðja pað að halda áfram að mæla með fiskneyslu 2-3 sinnum í viku sem aðalmáltíð, helst vegna peirra næringarefna sem finna

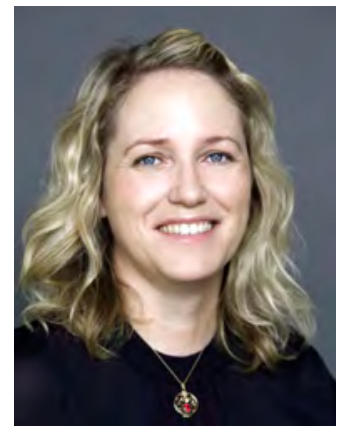

Jóhanna E. Torfadóttir

næringar- og lýðheilsufræðingur, PhD. Sérfræðingur í fræðslu og forvörnum hjá Krabbameinsfélagi Íslands og rannsóknarsérfræðingur við Læknadeild Hí.

\section{jet@hi.is}

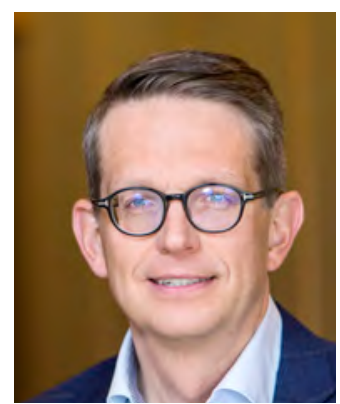

\section{Thor Aspelund}

tölfræðingur PhD. Prófessor við Miðstöð í lýðheilsuvísindum í Læknadeild Háskóla Íslands og tölfræðingur hjá Hjartavernd.

thor@hi.is

\section{Flexitarian diet to the rescue}

Jóhanna: Specialist, Education \& Prevention department, Icelandic Cancer Society

Thor: Research specialist, Centre for Public Health Sciences, University of Iceland

doi.org/10.17992//bl.2019.06.234 
má í sjávarfangi sem erfitt er að fá annars staðar úr fæðunni, svo sem joð, D-vítamín og langar omega-3 fitusýrur (tvö síðastnefnd aðallega frá feitum fiski). En pá verður framleiðslan að vera sjálfbær.

Í dag horfum við fram á að breytinga er pörf og pað strax ef takast á að fæða 10 milljarða manna. Stór páttur í peirri breytingu er að minnka neyslu á rauðu kjöti og auka neyslu á fæðu úr jurtaríkinu. Samkvæmt síðustu mataræðiskönnun frá 2010/11 sást að tíðni kjötneyslu jókst frá árinu 2002. Einnig hefur EL fylgst með mataræði landsmanna gegnum fæðuframboðstölur sem gefa ákveðna vísbendingu sem taka parf pó með fyrirvara par sem fjöldi ferðamanna og rýrnun getur haft talsverð áhrif. Síðstu fæðuframboðstölur frá árinu 2014 sýna að hver landsmaður neytti að meðaltali 93 $\mathrm{g}$ af rauðu kjöti daglega sem er rétt um ráðlagður skammtur heillar viku samkvæmt viðmiðum úr EAT-greininni.

Rannsókn um Heilsu og líðan Íslendinga (18-79 ára) á vegum EL frá 2017 sýnir að pað vantar mikið uppá að farið sé eftir ráðleggingum um mataræði með tilliti til neyslu ávaxta og grænmetis. Mögulega eru sóknarfæri núna par sem sífellt fleiri eru orðnir meðvit- aðir um pað hvaða umhverfisáhrif matvælaframleiðsla hefur og vilja breyta mataræði sínu til að leggja sitt af mörkum til að draga úr peim áhrifum. Ennfremur mætti endurskoða ráðleggingar um mataræði á vegum EL og taka tillit til sjálfbærni og umhverfisáhrifa eins og vísindamenn EAT-hópsins leggja til.

Flexitarian mataræði getur verið viðmið til að stefna að fyrir pá sem vilja breyta neysluvenjum til bættrar heilsu og minnka ágang á gæði jarðar.

\section{Heimildir}

1. Willett $W$, Rockstrom J, Loken B, Springmann M, Lang T, Vermeulen S, et al. Food in the Anthropocene: the EAT-Lancet Commission on healthy diets from sustainable food systems. Lancet. 2019;393(10170):447-92.

2. Global Panel on Agriculture and Food Systems for Nutrition. Food systems and diets: Facing the challenges of the 21st century. London, UK. 2016.

3. Aspelund T, Gudnason V, Magnusdottir BT, Andersen K, Sigurdsson G, Thorsson B, et al. Analysing the large decline in coronary heart disease mortality in the Icelandic population aged 25-74 between the years 1981 and 2006. PloS one. 2010;5(11):e13957.

4. Springmann M, Wiebe K, Mason-D'Croz D, Sulser TB, Rayner M, Scarborough P. Health and nutritional aspects of sustainable diet strategies and their association with environmental impacts: a global modelling analysis with country-level detail. Lancet Planet Health. 2018;2(10):e451-e61. 